\title{
DAYA TERIMA PRODUK PASTA GIGI DARI LIMBAH KULIT PISANG
}

\author{
Power To Receive Dental Pasta Products From Banana Skin Waste
}

\author{
Nabila Novitasari ${ }^{1)^{*}}$, Nor Aini ${ }^{1)}$, Febriana Arianti' ${ }^{2}$, Irfany Rupiwardani ${ }^{3 \text { ) }}$ \\ 1)Mahasiwa S1 prodi kesehatan lingkungan, Stikes Widyagama Husada \\ ${ }^{2)}$ Mahasiwa S1 prodi kebidanan, Stikes Widyagama Husada \\ 3)Staf Pengajar prodi kesehatan lingkungan, Stikes Widyagama Husada \\ email: nabilanovita25@gmail.com
}

\begin{abstract}
Banana skin is a waste that is not utilized by the community. During this time banana plants usually require banana leaves for traditional food packaging. This is because people's knowledge is still minimal about processing banana skin even though the banana peel we usually dispose of every day contains organic and inorganic substances. The mineral content of vitamin $C$ and fasfor in banana skin is very high. The purpose of this study was to find out the consumer acceptance of three toothpaste products. The non-parametric statistical method uses the Friedman Test and the determination of the best treatment uses the index of effectiveness. The results showed that the best combination of treatments on consumer acceptance of toothpaste in an organoleptic manner was obtained from the product market dental unit $(Y)$ with a product value of 0.0,513 with the following characteristics: 28 , and aroma 3.68
\end{abstract}

Keywords: Banana Skin, toothpaste, waste

\begin{abstract}
ABSTRAK
Kulit pisang merupakan limbah yang tidak dimanfaatkan oleh masyarakat. Selama ini tanaman pisang biasanya memerlukan daun pisang untuk pengemasan makanan tradisonal. Hal ini dikarenakan pengetahuan masyarakat masih minim tentang pengolahan kulit pisang padahal Kulit pisang yang biasa kita buang setiap hari mengandung zat-zat organik maupun anorganik. Kandungan mineral vitamin $C$, dan fasfor dalam kulit pisang sangatlah tinggi. Tujuan dari penelitian ini adalah untuk mengetahui daya terima konsumen terhadap tiga produk pasta gigi. Metode statistik non parametrik menggunakan Uji Friedman dan penentuan perlakuan terbaik menggunakan indek efektifitas. Hasil penelitian menunjukkan bahwa kombinasi perlakuan terbaik pada daya terima konsumen terhadap pasta gigi secara organoleptik didapatkan dari oasta gigi pasaran produk (Y) dengan nilai produk sebesar 0,0,513 dengan karakteristik sebagai berikut: rerata nilai tingkat kesukaan panelis terhadap rasa 2,72 warna 3,28, dan aroma 3,68
\end{abstract}

Kata kunci: kulit pisang, pasta gigi, limbah

\section{PENDAHULUAN}

Pisang mengandung Fosfor dalam jumlah yang cukup, yang bermanfaat dalam perkembangan otak dan kemampuan akal, seperti kecerdasan, berpikir dan menghafal. Pisang juga bermanfaat untuk radang mulut dan gusi karena ia mengandung fluoride, yaitu suatu zat penyeteril. Pisang mengandung zat besi, dimana vitamain $\mathrm{D}$ juga berguna untuk memperkuat gigi pada proses pembentukan gigi (Danni, 2002).

Manfaat pisang untuk kesehatan diantaranya pencegahan Osteomalasia pada anak dan Osteoporosis pada orang dewasa (tua), dan kekurangan kalsium pada wanita hamil dan ibu menyusui, karena mengandung jumlah kalsium yang cukup, 
yaitu setiap $1 \mathrm{~kg}$ pisang mengandung $1 \mathrm{gr}$ kalsium. Kebutuhan harian kalsium untuk tubuh adalah 1,5 gram, dan kalsium pisang lebih mudah dicerna dibandingkan kalsium susu (Al Battar, 2013).

Kulit pisang mengandung zat organic maupun anorganik. Kandungan mineral dan, kandungan kalsium yang cukup tinggi. Selain itu,. Kandungan dalam kulit pisang yang paling banyak adalah air, kalsium, fosfor dan vitamin C. Keempat bahan tersebut sangatlah berguna bagi tubuh kita terutama gigi. Kandungan gizi yang terdapat dibuah pisang per 100 gram bahan yaitu air (garam) 75.00, Energi (K), Karbohidrat (gram), protein (gram), lemak gram), Ca (Mg), P (Mg), Vitamin A (Mg), Vitamin B-1 (Mg), Vitamin C (Mg) (Mulyanti, 2005). Kulit pisang adalah bahan alami yang mengandung saponin yang dapat memutihkan gigi (Irima, 2018).

Pengolahan pisang khususnya masih Sangat terbatas pada pemanfaatan buahnya saja sehingga bagian lainya seperti kulit pisang, umunya hanya dimanfaatkan sebagai pakan ternak atau di buang begitu saja. Kulit pisang mengandung komponen mineral dan fitokimia. Komponen mineral kulit pisang terdiri dari potassium, calcium, natrium, mangan, dan besi. Sedangkan komponen fitokimia kulit pisang terdiri dari alkaloid, flafonoit, fenol, tannin, dan saponin (Satria, 2009).

Saponin adalah glukosida dengan karekteristik foming yaitu busa yang dapat bertindak sebagai pembersih. Saponin terdiri dari polycylic aglycones dan terikat ke satu atau lebih rantai gula (Mulyono, 2016), sehingga saponin dapat berfungsi sebagai pembersih dan memutihkan gigi. Kalium dan mangan yang terdapat pada kulit pisang juga meiliki fungsi yang sama seperti saponin.

matang juga merupakan mineral yang dapat memutihkan gigi

Antioksidan merupakan senyawa yang mampu memperlambat atau mencegah efek berbahaya, efeke berbahaya dari radikal bebas. Kehadiran antioksidan didalam jaringan keras gigi dapat memproduksi oksigen sisa yang merupakan radikal bebas dengan cara melengkapi kekurangan elektrolit yang dimiliki radikal bebas sehingga reaksi berantai dari pembentukan radikal bebas menjadi terhambat. Radkal bebas akan menjadi stabil setelah menerima antielectron dari antioksidan (Sugianti, 2012).

Hasil analisis secara statistik pasta gigi kulit pisang dengan konsentrasi $15 \%$ memiliki efektivitas yang signifikan sebagai bahan alami pemutih gigi (Maesaroh dan Nurhayati, 2019).

\section{Bahan}

\section{BAHAN DAN METODE}

Bahan yang digunakan dalam penelitian ini adalah kulit pisang, arang, garam, baking powder, dan soda kue.

\section{Alat}

Alat-alat yang digunakan dalam penelitian ini meliputi, kompor gas, Tabung LPG, baskom, sendok, saringan, panci, blender, box, dan cobek lesung.

\section{Rancangan Penelitian}

Rancangan yang digunakan dalam penelitian ini menggunakan 3 produk dari 2 produk yang beredar di pasaran dengan berbahan baku pisang (X dan Y) terhadap produk PKM pasta gigi Paslisang.

\section{Pengamatan}

Pengamatan dilakukan terhadap produk pasta gigi pasaran dan paslisang dari 25 panelis yang tidak terlatih.

\section{Analisis Data}

Data hasil uji organoleptik dianalisis dengan metode statistik non parametrik menggunakan Uji Friedman dengan $(\alpha=$ 0,05), sedangkan perlakuan terbaik menggunakan indek efektifitas.

\section{HASIL DAN PEMBAHASAN}

\section{Aroma}


Hasil uji organoleptik menyajikan bahwa rerata ranking kesukaan panelis terhadap aroma dari kombinasi perlakuan pasta gigi pasaran dengan paslisag berkisar antara 2,36-3,68. Semakin tinggi rerata ranking kesukaan panelis, maka tingkat kesukaan panelis terhadap aroma semakin besar. Tabel 1 memperlihatkan rerata ranking tingkat kesukaan panelis terhadap aroma.

Tabel 1. Rerata tingkat kesukaan panelis terhadap aroma

\begin{tabular}{lc}
\hline \multicolumn{1}{c}{ Kombinasi Perlakuan } & Rerata \\
\hline Pasta gigi pasaran produk (X) & 2,36 \\
Pasta gigi pasaran produk (Y) & 3,68 \\
Pasta gigi produk paslisang & 2,88 \\
\hline
\end{tabular}

Tabel 1 memperlihatkan rerata nilai kesukaan panelis terhadap aroma pada berbagai kombinasi perlakuan mempunyai nilai terendah sebesar 2,36 dari kombinasi perlakuan Pasta gigi pasaran produk (X) Nilai tertinggi tingkat kesukaan panelis terhadap aroma sebesar 3,68 didapatkan dari kombinasi perlakuan Pasta gigi pasaran produk (Y).

Hasil analisis Uji Friedman $(\alpha=0,05)$ berdasarkan uji perbandingan pada berbagai kombinasi perlakuan memberikan pengaruh nyata terhadap rerata kesukaan aroma terhadap kombinasi perlakuan pasta gigi pasaran dengan paslisang. Kombinasi perlakuan terbaik tingkat kesukaan panelis terhadap aroma diperoleh dari kombinasi perlakuan Pasta gigi pasaran produk (Y). Menurut panelis penambahan aroma buah pisang yang segar yang sangat wangi dan menyegarkan, sehingga menimbulkan selera untuk menggunakan pasta gigi setiap harinya.

\section{Warna}

Hasil uji organoleptik menyajikan bahwa rerata ranking kesukaan panelis terhadap warna pasta gigi produk pasaran dan paslisang berkisar antara 2,72-4,32. Semakin tinggi rerata ranking kesukaan panelis, maka tingkat kesukaan panelis terhadap warna semakin besar. Tabel 2 memperlihatkan rerata ranking tingkat kesukaan panelis terhadap warna.

Tabel 2. Rerata tingkat kesukaan panelis terhadap warna

\begin{tabular}{lc}
\hline \multicolumn{1}{c}{ Kombinasi Perlakuan } & Rerata \\
\hline Pasta gigi pasaran produk (X) & 4,32 \\
Pasta gigi pasaran produk (y) & 3,28 \\
Pasta gigi produk paslisang & 2,72 \\
\hline
\end{tabular}

Tabel 2 memperlihatkan rerata nilai kesukaan panelis terhadap warna pada berbagai warna mempunyai nilai terendah sebesar 2,72 dari kombinasi perlakuan pasta gigi paslisang. Nilai tertinggi tingkat kesukaan panelis terhadap warna sebesar 4,32 didapatkan dari Pasta gigi pasaran produk $(\mathrm{X})$

Hasil analisis Uji Friedman $(\alpha=0,05)$ berdasarkan uji perbandingan pada berbagai kombinasi perlakuan pada rasa memberikan pengaruh nyata terhadap rerata kesukaan warna terhadap kombinasi perlakuan pasta gigi produk pasaran dengan paslisang. Kombinasi perlakuan terbaik tingkat kesukaan panelis terhadap warna diperoleh dari kombinasi perlakuan Pasta gigi pasaran produk $(\mathrm{X})$, warna yang ditimbulkan oleh Pasta gigi pasaran produk (X) ini sangat menarik yaitu kuning seperti buah pisang.

Rasa

Hasil uji organoleptik menyajikan bahwa rerata ranking kesukaan panelis terhadap rasa dari kombinasi perlakuan pasta gigi produk pasaran dan paslisang berkisar antara 2,44-3,56. Semakin tinggi rerata ranking kesukaan panelis, maka tingkat kesukaan panelis terhadap rasa semakin besar. Tabel 3 memperlihatkan rerata ranking tingkat kesukaan panelis terhadap rasa.

Tabel 3. Rerata tingkat kesukaan panelis terhadap rasa

\begin{tabular}{lc}
\hline \multicolumn{1}{c}{ Kombinasi Perlakuan } & Rerata \\
\hline Pasta gigi pasaran produk (X) & 2,44 \\
Pasta gigi pasaran produk (Y) & 2,72 \\
Pasta gigi produk paslisang & 3,56 \\
\hline
\end{tabular}


Tabel 3 memperlihatkan rerata nilai kesukaan panelis terhadap rasa pada berbagai kombinasi perlakuan pasta gigi produk pasaran dan paslisang mempunyai nilai terendah sebesar 2,72 dari Pasta gigi pasaran produk (Y). Nilai tertinggi tingkat kesukaan panelis terhadap rasa sebesar 3,56 didapatkan dari pasta gigi paslisang.

Hasil analisis Uji Friedman $(\alpha=0,05)$ berdasarkan uji perbandingan pada berbagai kombinasi perlakuan memberikan pengaruh nyata terhadap rerata kesukaan rasa terhadap kombinasi perlakuan pasta gigi produk pasaran dan paslisanag. Kombinasi perlakuan terbaik tingkat kesukaan panelis terhadap rasa diperoleh dari kombinasi perlakuan pasta gigi paslisang. Menurut panelis pasta gigi paslisang sangat digemari oleh panelis, karena terdapat rasa buah pisang dan tidak terlalu manis.

\section{Pemilihan Perlakuan Terbaik}

Penentuan perlakuan terbaik berbagai kombinasi perlakuan pasta gigi produk pasaran dan paslisang dilakukan dengan menggunakan metode indeks efektivitas. Hasil uji penentuan kombinasi perlakuan terbaik diperlihatkan pada Tabel 4.

Tabel 4. Nilai produk perlakuan terbaik

\begin{tabular}{lcccc}
\hline $\begin{array}{l}\text { Kombinasi } \\
\text { Perlakuan }\end{array}$ & Warna & Rasa & Aroma & $\begin{array}{c}\text { Nilai } \\
\text { Produk }\end{array}$ \\
\hline $\begin{array}{l}\text { Pasta gigi } \\
\text { pasaran } \\
\text { produk (X) }\end{array}$ & 4,32 & 2,44 & 2,36 & 0.441 \\
$\begin{array}{l}\text { Pasta gigi } \\
\text { pasaran } \\
\text { produk (Y) }\end{array}$ & $\mathbf{3 , 2 8}$ & $\mathbf{2 , 7 2}$ & $\mathbf{3 , 6 8}$ & $\mathbf{0 , 5 1 3 *}$ \\
$\begin{array}{l}\text { Pasta gigi } \\
\text { paslisang }\end{array}$ & 2,72 & 3,56 & 2,88 & 0,414 \\
*=Perlakuan terbaik & & &
\end{tabular}

Tabel 4 memperlihatkan hasil uji perlakuan terbaik didapatkan dari kombinasi perlakuan pasta gigi pasaran produk $(\mathrm{Y})$ dengan nilai produk sebesar 0,513 dengan karakteristik sebagai berikut: rerata nilai tingkat kesukaan panelis terhadap rasa 2,72; warna 3,28 dan aroma 3,68 .
Kombinasi perlakuan terbaik secara organoleptik diperoleh dari kombinasi perlakuan pasta gigi pasaran produk (Y) dengan nilai produk sebesar 0,513 dengan karakteristik sebagai berikut: rerata nilai tingkat kesukaan panelis terhadap rasa 2,72; warna 3,28 dan aroma 3,68.

\section{UCAPAN TERIMA KASIH}

Penulis mengucapkan terima kasih kepada seluruh pihak yang telah membantu dalam pelaksanaan kegiatan PKM dan seluruh pihak yang telah membantu dalam penelitian ini terutama kepada DPRM Dikti dan STIKES Widyagama Husada Malang.

\section{DAFTAR PUSTAKA}

Al Battar, S. (2013). Keajaiban manfaat buah pisang, http://www.arrahmah.com/news/201 3/02/20/keajaiban -manfaat-buahpisang. Diakses 19 Juni 2019.

Danni, A. (2002). Pemanfaatan limbah kulit pisang menjadi pectin. Tehnik Kimia, Fakultas Tehnik Universitas Dipnegoro Semarang.

Irima, L. A. (2018). Pengaruh Ekstrak Kulit Pisang Ambon (Musa acuminata) $100 \%$ terhadap Perubahan Warna Gigi Permanen Manusia setelah Diskolorasi Kopi (In-Vitro).

Maesaroh, I., \& Nurhayati, E. (2019). Uji efektivitas penggunaan pasta gigi ekstrak kulit pisang kepok (Musaparadisiaca. L) sebagai pemuth gigi. Cerata Jurnal Ilmu Farmasi, 9(1); 39-47

Mulyanti, S. (2005). Teknologi pangan, trubus agri sarana, Surabaya.

Mulyono LA, Hamidah, \& Irawan B. (2016). Pengelompokan empat varietus pisang (Musa acuminate Colla) melaului pendekatan fenetik. Surabaya: Departemen Biologi, Fakultas Sains dan Teknolgi, Universitas Airlangga, 
Rochmah, Y.S., \& Minidian, F. (2014).

Pengaruh penyuluhan terhadapa perubahan pengetahua bagi ibu-ibu PKK Kelurahan Penggaron Lor tentang pemanfaatan tanaman pisang sebagai media menjaga kesehatan gigi dan mulut . Odonto Dental Journal, 1(2).

Sugianti, N. (2012). Effect extract rosella (Hibiscussab driffa) as an alternative to natural tooth bleaching agent on external discoloration case. Incisive Dental, 1(2), 5-9. 